\title{
SECERCAH PANDANG MENGUNGKAP KASUS NIKAH SIRRI DI INDONESIA
}

\author{
Kurnia Muhajarah \\ Universitas Islam Negeri (UIN) Walisongo Semarang \\ e-mail: kurniamuhajarah1@gmail.com
}

\begin{abstract}
Abstrak
Salah satu bentuk pelecehan terhadap perempuan yang dapat menghilangkan hak-haknya adalah nikah sirri, yakni melaksanakan pernikahan rahasia. Bahkan tidak jarang terjadi lahir hubungan seks di luar pernikahan dengan dalih nikah sirri. Inilah yang kemudian melahirkan istilah lelaki dan perempuan piaraan. Metode penelitian ini menggunakan jenis penelitian kualitatif. Hasil pembahasan menunjukkan bahwa beberapa tahun terakhir terjadi pergeseran makna suci pernikahan. Fenomena ini ditandai dengan maraknya prosesi nikah sirri atau nikah di bawah tangan. Ada berbagai pendapat di kalangan ulama mengenai halal tidaknya nikah sirri ini. Sebagian ulama menilai pernikahan sirri dihalalkan asal memenuhi syarat dan rukun nikah oleh negara. Nikah sirri selain berpotensi menimbulkan fitnah, juga secara hukum sangat merugikan kaum wanita. Meski "sah" menurut agama, namun pernikahan siri tidak barakah (berkah) dan luput dari perlindungan hukum perkawinan. Dengan buku nikah menjadi bukti pernikahan yang dilakukan telah dicatat oleh negara. Suami dan isteri mempunyai hak yang sama dalam hukum perkawinan.
\end{abstract}

Kata Kunci: nikah; nikah sirri; penanganan

\section{A. Pendahuluan}

Secara etimologi, istilah nikah sirri adalah kata yang berasal dari bahasa Arab yang secara umum telah diserap dalam Bahasa Indonesia. Pernikahan sirri yang dalam kitab fiqh disebut (الزواج السرى) sebagai rangkaian dari dua kata yaitu (الزواج) dan (السرى).

Istilah nikah (الزواج) merupakan bentuk masdar (زوج) yang menurut bahasa berarti pernikahan. Sedangkan istilah sirri (السرى) merupakan bentuk masdar dari kata (سر) yang secara bahasa berarti 'rahasia'. Berdasarkan pengertian tersebut, maka padanan kata az-zawaj as-siri (الزواج السرى) dapat diartikan pernikahan yang dilakukan secara sembunyi-sembunyi/rahasia. 
Secara terminologi, nikah sirri yang dikenal oleh masyarakat Indonesia sekarang ini ialah pernikahan yang dilakukan dengan memenuhi rukun dan syarat yang ditetapkan agama, tetapi tidak dilakukan di hadapan Pegawai Pencatat Nikah sebagai aparat resmi pemerintah atau perkawinan yang tidak dicatatkan di Kantor Urusan Agama bagi yang beragama Islam atau di Kantor Catatan Sipil bagi yang tidak beragama Islam, sehingga tidak mempunyai Akta Nikah yang dikeluarkan oleh pemerintah. Perkawinan yang demikian di kalangan masyarakat selain dikenal dengan istilah nikah sirri, dikenal juga dengan sebutan nikah di bawah tangan. ${ }^{1}$

Studi ini dimaksudkan untuk menjawab permasalahan bagaimana problematika nikah sirri? Bagaimana upaya penanganan nikah sirri? Permasalahan tersebut dibahas dengan data primer yaitu buku-buku atau kajian penelitian kepustakaan. Dalam pengumpulan data, peneliti menempuh langkah-langkah melalui riset kepustakaan (library research). Dalam menganalisis data, digunakan metode induktif dan metode komparatif.

\section{B. Fenomena Nikah Sirri}

Menurut ulama Malikiyah, nikah sirri adalah pernikahan yang tidak dipublikasikan meskipun telah dipersaksikan, namun dalam hal ini, keberadaan saksi tetap dimintakan untuk tidak menyebarluaskan pernikahan sirri tersebut kepada khayalak umum. ${ }^{2}$ Menurut Ibnu Hazm, nikah sirri adalah nikah yang diketahui kurang dari dua orang, namun jika lebih dari dua orang maka berarti nikah itu tidak rahasia lagi (sirri). Begitu pula halnya dengan pernikahan yang telah dihadiri oleh lima orang, yaitu calon suami (an-nakih), calon istri (al-mankuhah), wali (al-munkih) dan dua orang saksi tidak lagi dinamakan sirri. ${ }^{3}$ Seorang ulama terkemuka yang pernah menjabat Rektor Universitas al-Azhar di Kairo Mesir, yaitu Mahmud Syaltut dalam kitabnya al-Fatawa menyatakan, bahwa az-zawaj as-sirri merupakan nikah yang tidak menghadirkan saksi, tanpa pengumuman

1Burhanuddin, Nikah Siri Menjawab Semua Pertanyaan tentang Nikah Siri, (Yogyakarta: Pustaka Yustisia, 2010), h. 13.

2Ibnu Rusyd, Bidâyah al Mujtahid Wa Nihâyah al Muqtasid, Juz.II, (Beirut: Dâr Al-Jill 1409 H/1989M), h. 13.

3lbnu Hazm, al-Muhalla, ditahqiq oleh Muhammad Saqir, juz ix: 465. 
(ilan), serta tanpa pencatatan resmi meskipun pasangan tetap berlangsung dalam status pernikahan yang tersembunyi. ${ }^{4}$ Wahbah al-Zuhaili mendefinisikan nikah sirri sebagai nikah yang oleh mempelai laki-laki (suami) diminta kepada pra saksi untuk merahasiakan, baik kepada keluarga (istri), saksi maupun kepada masyarakat. ${ }^{5}$

Apabila melihat rumusan dari para ahli di atas tentang nikah sirri, tampaklah ada yang menganggap nikah sirri itu nikah yang tidak memenuhi rukun dan syarat nikah, ada juga yang menganggap nikah sirri itu nikah tidak tercatat atau di bawah tangan, meskipun memenuhi rukun dan syarat nikah. Dengan demikian ada yang berpendapat, nikah sirri sama dengan nikah tidak tercatat atau nikah di bawah tangan.

Menurut penulis, jika nikah sirri hanya diartikan sebagai nikah yang tidak memenuhi rukun dan syarat nikah, maka hal tersebut merupakan pengertian nikah sirri dalam arti sempit. Demikian pula, jika nikah sirri hanya diartikan sebagai nikah yang memenuhi syarat dan rukun nikah namun tidak dicatat, maka yang demikian juga merupakan pengertian nikah sirri dalam arti sempit. Menurut penulis, nikah sirri dalam arti luas mencakup dua bentuk pernikahan: 1) nikah yang tidak memenuhi rukun dan syarat nikah, atau juga 2) nikah yang sudah memenuhi rukun dan syarat nikah namun belum/tidak dicatatkan di KUA Kecamatan bagi yang beragama Islam. Dengan demikian nikah sirri lebih luas pengertiannya dari pengertian nikah tidak tercatat.

Oleh karena, dari pengamatan penulis di lapangan, maka penulis merumuskan nikah sirri sebagai berikut. Terdapat dua macam nikah sirri, yaitu:

Pertama, akad nikahnya dilakukan tanpa hadirnya orang tua (wali). Pernikahan bentuk pertama ini akadnya hanya dihadiri mempelai laki-laki, mempelai perempuan, dua orang saksi, dan guru atau ulama yang menikahkan tanpa memperoleh pendelegasian kuasa dari wali nikah yang berhak. Padahal dalam perkawinan Islam, unsur wali merupakan salah satu rukun. Tanpa adanya wali (izin wali nikah), keabsahannya dapat dipersoalkan. Meskipun dalam perkawinan itu terdapat orang yang menikahkan dan

\footnotetext{
${ }^{4}$ Mahmud Shaltut, al-Fatawa, (Kuwait: Dar al-Qalam, tth.), h. 268.

5Wahbah al-Zuhaili, al-Figh al-Islâmi wa Adillatuh, Juz VII, (Damaskus: Dar al-Fikr, 1989), h. 71 .
} 
bertindak sebagai "wali", yaitu guru atau ulama tersebut, dia bukanlah orang yang mendapat kuasa dari walinya dan ia bukan pula penguasa yang mempunyai hak untuk menikahkan. Kedua, lengkap dengan wali nikah. Akadnya dihadiri oleh mempelai laki-laki, wanita, wali nikah, dan dua orang saksi.

Kedua macam nikah sirri di atas berlangsung tanpa dicatatkan pada Pegawai Pencatat Nikah, padahal pencatatan ini adalah perintah undangundang sebagai perwujudan syiyasah syariah dari pemerintah yang harus ditaati untuk terwujudnya kemaslahatan umat dan memenuhi tuntutan kehidupan umat yang terus berkembang demi kepastian hukum.

Perkawinan merupakan peristiwa hukum yang penting sebagaimana kelahiran, kematian dan sebagainya. Sebagai peristiwa penting maka menurut penulis, perkawinan tidak cukup hanya dibuktikan dengan peristiwa itu sendiri. Harus ada bukti tertulis berdasarkan pencatatan di lembaga yang ditunjuk. Dengan pencatatan oleh pejabat yang berwenang, yang kemudian mengeluarkan akta berupa surat nikah, maka fungsi akta merupakan alat bukti sempurna (autentik).

Menurut penulis, nikah sirri pada dasarnya merupakan distorsi (penyimpangan) sosial yang kerap kali menimbulkan berbagai "kerepotan" madharat, sedang nikah yang tidak sirri sesungguhnya lebih banyak maslahatnya.

Menurut penulis, apabila "kerepotan" itu sampai muncul dalam bentuk sengketa menyangkut hak, maka menurut hukum akan diselesaikan oleh peradilan, dalam hal ini oleh Peradilan Agama sebagai salah satu pelaku kekuasaan kehakiman bagi rakyat pencari keadilan yang beragama Islam mengenai perkara tertentu (Pasal 2 Undang-Undang Nomor 3 Tahun 2006, sebagaimana telah diubah oleh Undang-Undang Nomor 50 Tahun 2009 tentang perubahan kedua atas Undang-Undang Nomor 7 Tahun 1989 Tentang Peradilan Agama).

Perkawinan bertujuan untuk mewujudkan kehidupan rumah tangga yang sakinah, mawadah dan rahmah. Agar terjamin ketertibannya, maka harus dicatat oleh Pegawai Pencatatan Nikah.

Menurut penulis, perkawinan yang dilakukan di luar pengawasan Pegawai Pencatat Nikah tidak mempunyai kekuatan dan perlindungan hukum, karena perkawinan hanya dapat dibuktikan dengan akta nikah yang dibuat oleh Pegawai Pencatat Nikah. 
Perintah pencatatan perkawinan adalah semangat Undang-undang Nomor 1 Tahun 1974 tentang Perkawinan. Undang-undang ini sendiri memperkuat hukum Islam, yaitu meletakkan perkawinan sebagai perikatan suci seorang laki-laki dengan wanita untuk membentuk rumah tangga yang kekal dan bahagia, diridhai Tuhan Yang Maha Esa. Ibnu Juzai menyatakan, apabila ada pernikahan sirri maka pernikahan tersebut harus dibatalkan (fasakh). ${ }^{6}$

\section{Fenomena Nikah Sirri di Kalangan Artis dan Pejabat}

Beberapa contoh nikah sirri dapat penulis ungkapkan sebagai berikut. Kasus perkawinan sirri antara mantan pejabat negara, kala itu menjabat sebagai Sekretaris Negara RI, Letnan Jenderal (Purn) M dengan MM, seorang artis penyanyi yang juga terkenal di kala itu, sampai menghasilkan buah dari perkawinan sirri seorang anak laki-laki, yang bernama MIR. Perkawinan tersebut hanya berlangsung kurang lebih 1,5 tahun. Sampai saat ini, keluarga almarhum Moerdiono masih belum sepenuhnya menerima MIR sebagai anak kandung M.7

Begitupun perkawinan sirri antara raja dangdut, Rhoma Irama dengan Angel Elga juga seorang selebriti, dan perkawinan sirri antara Dewi Persik, seorang artis penyanyi dangdut dengan Aldi Taher juga seorang aktor sinetron, yang kesemuanya berakhir dengan kekecewaan dan kesedihan, lagi-lagi wanitalah yang banyak mengalami kerugian dan penderitaan. Selengkapnya, penulis cantumkan kasus-kasus nikah sirri sebagai berikut:

\section{Pernikahan Sirri ES (Penjahit sekaligus Paranormal) ${ }^{8}$}

ES memang memiliki delapan istri, namun apakah ES menikahkan kedelapan istrinya melalui Kantor Urusan Agam (KUA)? Saat Okezone

${ }^{6}$ Ibnu Juzai, Al-Qawanin al-Fiqhiyyah, (Beirut: Dar al-Kitab al-ljtimiyyah, t.th.), h. 131.

7Pada Februari 2012 lalu, Mahkamah Konstitusi (MK) membuat putusan yang cukup mengejutkan banyak pihak, yaitu dikeluarkannya Putusan Mahkamah Konstitusi (MK) Nomor 46/PUU-VIII/2010 terkait kedudukan hukum bagi anak luar kawin. Putusan ini lantas mengundang pro dan kontra dari berbagai pihak, baik dari kalangan praktisi hukum, akademisi, LSM, MUI, bahkan masyarakat. Putusan MK mengenai pengakuan anak di luar perkawinan "mengejutkan". Walaupun melegakan sejumlah pihak, tapi akan ada permasalahan baru yang timbul dari putusan mahkamah konstitusi tersebut. 2015.

8http://berita.okemetro.com/id/read/2013/04/05/33/787139, diakses tanggal 13 Oktober 
menyambangi KUA Kecamatan Kebon Jeruk, Jakarta Barat, ternyata nama ES atau IH tidak tertera dalam data. "Selama ini tidak ada yang namanya ES," ujar salah satu karyawan KUA Kecamatan Kebon Jeruk, Jakarta Barat, Harmain, Jumat (5/4/2013).

Pihak KUA sendiri belum mendapatkan informasi mengenai ES dahulunya tukang jahit itu pernah mendaftarkan namanya saat ingin menikah. Sejauh ini kata Harmain, pihaknya belum mendapatkan data mengenai ES. ${ }^{9}$

Tujuh Istri ES (Tertua Ny HM, A, D, H, N, Istri keenam An alias Ani awalnya pembantu ES, yang juga merupakan keponakan AW dan terakhir adalah NS yang juga merupakan mantan istri SDC. Anehnya semua mau berpakaian seragam, berkalung seragam, ada kelainan apa ini?10

Setidaknya ada 5 hukum yang dilecehkan ES, mulai dari Hukum Perkawinan, Hukum Gender, Hukum Waris, Hukum Perlindungan Anak, hingga Hukum Administrasi Negara. Sadarkah para istri-istri ES akibat hukum perkawinan tersebut?. Dapat dipastikan perkawinan ES adalah "kawin di bawah tangan", "kawin siri" atau "nikah sirri" yang hanya dilakukan berdasarkan aturan agama atau istiadat belaka, konsekuensinya tidak tercatat pada Kantor Pegawai Pencatat Nikah (KUA) Alias Perkawianan ES tidak memiliki kekuatan hukum. ${ }^{11}$

Penasehat Majelis Ulama Indonesia (MUI) Kabupaten Sumedang KH. Muhamamad Aliyuddin mengemukakan, fatwa MUI agar ES melepaskan wanita yang dianggap istri kelima dan seterusnya itu merupakan tuntutan ajaran Agama Islam dalam al-Qur'an. ES harus tunduk dan patuh terhadap ajaran Allah yang disuarakan melalui MUI. "Wanita yang dianggap istri kelima, keenam dan seterusnya itu bukan istri karena pernikahannya tidak sah. Jadi tidak perlu dicerai, tapi dilepas. MUI tidak bilang dicerai, tapi dilepas," katanya menjawab pertanyaan MUI online di Jakarta, Kamis (2/5) sore, menanggapi pernyataan kuasa hukum ES.12

9Ibid.

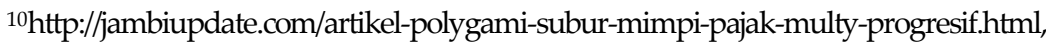
diakses tanggal 13 Oktober 2015.

${ }^{11} \mathrm{Ibid}$.

12 http://www.mui.or.id/index.php?start=9, diakses tanggal 13 Oktober 2015 


\section{Pernikahan Sirri $\mathrm{ZMZ}^{13}$}

ZMZ ini dikenal dengan gelar Kyai Sejuta Umat. Meski bergelar "hanya" sejuta, namun honornya bernilai puluhan juta rupiah sekali manggung, dan harus dibayar di muka. Itu belum termasuk akomodasi dan transportasi.

Sebelum kisah asmaranya dengan AS terungkap ke publik sejak awal Oktober 2010 ini, jauh sebelumnya, sekitar satu dasawarsa lalu, Tabloid Citra pernah menjadikan foto mesra $\mathrm{ZMZ}$ sejuta umat ini sebagai cover depan. Pada cover depan itu, ZMZ sedang merangkul bahu ND, yang kini menjadi istri FA.

ND selama ini dikenal sebagai penyanyi lagu-lagu melankolis, pemain sinetron dan film layar lebar, dan pernah menikah dengan laki-laki asal Brunei Darussalam.

Publikasi itu tentu saja merugikan ZMZ. Namun entah kenapa, insiden itu tak membuatnya terpuruk. Dari sudut ND, publikasi itu boleh jadi membawa keberuntungan. Setidaknya ia batal menjadi 'korban' sebagaimana terjadi pada pengakuan AS kini.

AS kini berusia 28 tahun. Ia mengaku, sembilan tahun lalu, ketika usianya masih 16 tahun, ia berkenalan dengan ZMZ kyai sejuta umat ini. Saat itu AS sang penyanyi dangdut ini sedang mengisi sebuah acara, di Bogor. Tentu saja saat itu AS tidak menduga sang kyai kondang juga ada di acara tersebut. "Di situ kami bertemu dan beliau meminta nomor telepon saya. Dari situ beliau sering menelepon saya hingga akhirnya meminta bersilaturahim ke rumah..."

Setiap berkunjung ke rumah orangtuanya, menurut AS, sang kyai banyak membawa buah tangan seperti durian, rambutan dan makanan lainnya. Sampai pada suatu ketika, di hadapan AS dan kedua orangtuanya, ZMZ menyampaikan maksudnya untuk menikahi AS. Namun karena usianya masih sangat muda, AS pun menolak.

Meski ditolak, upaya sang kyai tidak berhenti sampai di situ. Sang kyai kondang ini pun terus mendekati AS dengan berbagai cara, merayu ibu, bapak dan kakek AS. Karena AS tak pernah menanggapi ajakan menikah, beliau pun akhirnya menghilang dan menjauhi AS.

${ }^{13}$ http://umarabduh.blog.com/2012/03/10/1342/, diakses tanggal 13 Oktober 2015 
Masih menurut pengakuan AS, sebelum akhirnya pergi meninggalkan AS, di antara keduanya sempat terjalin hubungan mesra. "Saya dekat selama satu tahun lebih. Dia suka gandeng tangan aku di jalan. Tidak hanya itu saja, saya pun sering diminta menemani beliau sampai menginap bareng di luar kota. Jujur, saya malu karena itu bukan keinginan saya..." (okeZone News - Jum Okt 08, 2010 10:24 WIT)

AS sebenarnya malu mengungkap hubungan terlarangnya dengan sang kyai. Namun ia beralasan, hal itu dilakukannya agar tidak ada AS-AS yang lain jadi korban. Kemunculan AS membuka kisah lama dengan beliau itu memang sudah dipersiapkan dengan matang. Ia punya bukti berupa foto dan lain-lain. "Saya melakukan ini atas kemauan saya sendiri. Semoga dengan bicara ini, masyarakat tidak lagi dibohongi dengan isi ceramahnya. Saya baru ngomong sekarang karena sudah tidak kuat dan ini saatnya meledak..." (Oke Zone News - Jum Okt 08, 2010 09:55 WIT).

Ungkapan AS: "Semoga dengan bicara ini, masyarakat tidak lagi dibohongi dengan isi ceramahnya"; itu perlu dicermati. Soalnya, sebenarnya selama ini masyarakat sudah dibohongi oleh penceramah kondang itu, namun belum tersebar protes yang kuat. Karena kalau diprotes mungkin justru menjadi fitnah. Sehingga dikhawatirkan timbul madhorot.

\section{Pernikahan Sirri HRI ${ }^{14}$}

Ketika soal nikah sirri dipolemikkan dalam kaitan Rencana Undangundang Peradilan Agama, wartawan Harian Warta Kota rupanya segera teringat kepada HRI. Tak lain karena penyanyi dangdut yang berdakwah lewat lagu itu pernah melakukan pernikahan sirri setidaknya satu kali, dengan artis AL. Waktu itu sempat ada kehebohan karena sang raja dangdut itu didapati bertamu lewat tengah malam ke 'apartemen' AL. Tapi reda, setelah HRI mengumumkan telah menikah sirri dengan sang artis. Namun tak berapa lama, pernikahan sirri pasangan yang usianya berbeda jauh itu, berakhir dengan perpisahan.

Koran ibukota itu mengutip komentar HRI, "Menurut pandangan saya, orang-orang yang membuat aturan-aturan ancaman hukum bagi orang yang menikah atau kawin sirri itu adalah orang-orang yang atheis".

14 http://umarabduh.blog.com/2012/03/10/1342/, diakses tanggal 13 Oktober 2015. 
Atheis? Orang-orang Kementerian Agama yang ikut menyusun RUU itu, tidak ber-Tuhan dong sesuai pengertian terminologi atheis itu. HRI memperjelas maksudnya dalam menggunakan istilah atheis, "Bukan tidak beragama, tetapi tidak memihak dan tidak memahami agama".

Pada kutub pendapat yang berbeda, Dirjen Bimas Islam Kementerian Agama, Nazaruddin Umar, dikutip detikNews (Selasa, 16 Februari), latar belakang pengajuan RUU tentang Hukum Materiil Peradilan Agama yang antara lain memuat ketentuan pemidanaan bagi pelaku nikah sirri dan nikah kontrak, adalah masalah kemanusiaan. Banyak orang yang memilih memilih menikah sirri maupun nikah kontrak dengan dalih lebih baik begitu daripada zina. "Alasan menghindarkan dosa zina justru bisa menimbulkan dosa lainnya seperti penelantaran pasangan dan anak". Menurut sang Dirjen yang tentunya sangat memahami agama Islam, kasus meninggalkan pasangan begitu saja setelah pernikahan yang dicatatkan secara resmi sangat jarang dibandingkan nikah sirri atau nikah kontrak. Satu banding seribu. Anak-anak hasil pernikahan resmi yang dicatat KUA, lebih mudah mendapatkan hak-haknya seperti warisan, hak perwalian, dalam pembuatan KTP, paspor serta tunjangan kesehatan dan sebagainya.

\section{Pernikahan Sirri Mantan Bupati Garut, $\mathrm{AF}^{15}$}

Pada 14 Juli 2012, AF menikah lagi secara sirri dengan seorang gadis berusia 18 tahun dengan mengaku sebagai duda. Gadis bernama FO itu kemudian diceraikan empat hari kemudian, alasannya karena sang gadis disinyalir tidak perawan lagi setelah malam pertama mereka. Sang istri sirri itu diceraikan $\mathrm{AF}$ hanya melalui pesan singkat. Setelah perceraian itu, $\mathrm{AF}$ sempat mengirim pesan singkat kepada FO: "Hai perempuan jahat, aq minta seglaa pemberian aq dikembalikan".

Sang bupati sendiri menampik bahwa hubungannya dengan FO adalah pernikahan. Menurutnya, yang terjadi adalah sebuah hubungan emosional atau perikatan dengan komitmen yang disepakati kedua belah pihak. Dia menganggap bahwa masalah ini hanyalah politisasi dari lawan politiknya menjelang pilkada untuk menjegal dirinya.

Belum selesai soal persoalan nikah sirri kilat 4 hari dengan FO, sang bupati kembali tersandung kasus pernikahan singkat. Kali ini, seorang

15 http:/ / umarabduh.blog.com/2012/03/10/1342/, diakses tanggal 13 Oktober 2015 
wanita di Karawang, Jawa Barat, bernama SL mengaku dinikahi AF dengan usia pernikahan 2 bulan saja. Tapi cinta AF tak lama. Dia akhirnya memberikan surat talak atau cerai pada Shinta bulan Juni 2011 lalu. Lewat pesan blackberry messenger, talak itu dilayangkan. Tak jauh berbeda dengan AF yang menceraikan FO di Garut lewat SMS dengan alasan tidak perawan lagi. Namun, menurut sang bupati, isu menikah dengan SL, gadis Karawang hanyalah sebatas black campaign karena tidak lama lagi Garut akan menggelar Pilkada. Pada tanggal 3 Desember 2012, Bupati Garut AF sepakat berdamai dengan FO.

\section{Pernikahan Sirri AKH, Pimpinan DI/TII di Sulawesi Selatan}

Perkawinan usia muda dan sirri yang terjadi pada tahun 1956, antara Abdul Kahar Muzakar pimpinan DI/TII di Sulawesi Selatan kawin usia muda dan sirri dengan perempuan Indo Belanda yang bernama $C$ yang menjadi mualaf dan setia sampai Abdul Kahar Muzakar meningal dunia. ${ }^{16}$

\section{Pernikahan Sirri Putra Mahkota}

Perkawinan usia muda dan sirri yang terjadi pada tahun 2006, antara Putra Mahkota Kerajaan Kelantan Malaysia, F (37 tahun) dengan M (15 tahun), wanita cantik keturunan Perancis Indonesia berakhir dengan perceraian pada tahun 2008.

\section{Pernikahan Sirri NZ (Direktur PT. Rajawali Jakarta)}

Perkawinan sirri yang terjadi pada tahun 2007 antara NZ Direktur PT. Rajawali Jakarta, dengan RJ di lapangan Golf Tangerang yang berakhir dengan tragis dengan ditembak matinya NZ oleh suruhan AA, mantan Ketua KPK dalam kasus cinta segitiga.

\section{Penyebab Terjadinya Nikah Sirri}

Melihat fenomena dan fakta di atas, penulis berpendapat bahwa ada dua macam sebab dilakukannya nikah sirri:

Pertama, adanya faktor-faktor di luar kemampuan si pelaku seperti: 1) Si laki-laki dan perempuan masih kuliah, maka sambil menanti selesai

16Abdul Aziz Muzakar, Mengenang Sang Tokoh dari Timur. Fajar, 1998. h. 23. 
kuliah, mereka nikah sirri dulu untuk agar terhindar dari hal-hal yang dilarang agama; 2) Tidak adanya izin wali nikah (orangtua); 3) Sulitnya memperoleh izin dari istri dalam hal suami akan menikah lebih dari seorang; 4) Adanya kekhawatiran kehilangan hak pensiun janda,

Kedua, adanya pendapat bahwa pencatatan tidak merupakan perintah agama, tidak dilakukan di zaman Nabi.

Mengenai nikah sirri karena tidak adanya izin orang tua, tanpa wali nasab/wali hakim, alasannya pada umumnya didasarkan pada pendapat bahwa wali nasab, bahkan wali hakim, itu tidak wajib hukumnya; mereka menganggap bahwa hubungan dengan orang tua/wali adalah soal sopan santun atau tatakrama.

Kompilasi Hukum Islam Pasal 19 menegaskan bahwa wali nikah dalam perkawinan merupakan rukun yang harus dipenuhi bagi calon mempelai wanita. Wali inilah yang bertindak untuk menikahkannya. Menurut Pasal 20, wali terdiri dari wali nasab dan wali hakim.

\section{E. Upaya Preventif dan Curatif Nikah Siri}

Langkah-langkah yang harus diambil dalam mengatasi perkawinan sirri sebagai berikut: ${ }^{17}$

\section{Sebelum Terjadi Perkawinan Sirri}

Pertama, bagi para remaja dan calon pasangan yang belum kawin, atau akan menikah serta orang tua perlu penyuluhan hukum agar supaya sadar hukum. Dengan memberikan sosialisasi ke masyarakat akibat dan kerugian dari perkawinan sirri untuk membangun kesadaran hukum. Tujuannya agar perkawinan sirri tidak terjadi di masyarakat secara terus menerus.

Kedua, untuk kepentingan masa depan, bagi masyarakat yang terlanjur melakukan perkawinan sirri perlu mengadakan program pemutihan itsbat nikah oleh Kementerian Agama. Kementerian Agama punya program untuk mendata seluruh masyarakat yang tidak memiliki akta nikah, kemudian diisbatkan oleh pengadilan dengan biaya yang di tanggung oleh pemerintah. Butuh dana besar, tenaga serta waktu. Caranya dengan datang

17 Abdi Koro, Perlindungan Anak di Bawah Umur dalam Perkawinan Usia Muda dan Perkawinan Siri, Alumni, Bandung, 2012, h. 210 
ke Pengadilan Agama, mengikuti sidang, selanjutnya Pengadilan Agama akan mencatat tanggal pernikahan dan menerbitkan buku nikah.

Ketiga, bagi pasangan yang baru saja terlanjur melakukan kawin sirri dan belum punya anak, pengesahan perkawinannya dengan cara mengulang perkawinan atau dicatat di Kantor Urusan Agama setempat.

Keempat, memberdayakan Kantor Urusan Agama (KUA) untuk melakukan fungsi pengawasan. Kantor Urusan Agama perlu menyebarkan pengawas guna memantau pasangan yang menikah agar memiliki surat nikah. Apabila tidak ada surat, istri dihimbau segera minta surat nikah. Dengan begitu mereka datang mengurusnya ke Kantor Urusan Agama. Pengawasan ini dilakukan dengan menggerakkan penghulu di desa-desa dan kepala desa, agar setiap perkawinan harus melalui sepengetahuan RT dan RW. Cara ini layak diterapkan untuk memantau warga yang menikah supaya tercatat di Kantor Urusan Agama.

Kelima, perlu efektivitas kerja sama dengan pelbagai pihak, seperti LSM, organisasi perempuan dan pemerintah supaya melakukan koordinasi. Selama ini para LSM dan organisasi perempuan tidak punya payung hukum. Mereka bergerak sendiri-sendiri tanpa koordinasi dan kurang bisa memberikan pressure ke pihak-pihak yang melakukan perkawinan sirri. Harusnya LSM, organisasi perempuan bergandengan tangan mencegah perkawinan sirri.

Akhirnya, perkawinan sirri selalu mengorbankan pihak perempuan. Untuk menjaga keseimbangan itulah, diperlukan hukum yang memihak keadilan di antara laki-laki dan perempuan. Jangan ada korban bagi perempuan lagi.

\section{Upaya yang harus Dilakukan Apabila telah Terjadi Perkawinan Siri}

\section{a. Bagi yang Beragama Islam}

Mencatatkan perkawinan dengan istbat nikah. Bila yang bersangkutan beragama Islam, namun tak dapat membuktikan terjadinya perkawinan dengan akta nikah, dapat mengajukan permohonan istbat kawin (penetapan/pengesahan nikah) kepada Pengadilan Agama (Kompilasi Hukum Islam Pasal 7). Namun Istbat Nikah ini hanya dimungkinkan bila berkenaan dengan: 1) Dalam rangka penyelesaian perceraian; 2) Hilangnya akta nikah; 
3) Adanya keraguan tentang sah atau tidaknya salah satu syarat perkawinan; 4) Perkawinan terjadi sebelum berlakunya undang-undang no. 1 tahun 1974 tentang perkawinan; 5) Perkawinan yang dilakukan oleh mereka yang tidak mempunyai halangan perkawinan menurut Undangundang No. 1 Tahun 1974 Tentang Perkawinan. Artinya, bila ada salah satu dari kelima alasan di atas yang dapat dipergunakan, dapat segera mengajukan permohonan istbat nikah ke Pengadilan Agama. Sebaliknya, akan sulit bila tidak memenuhi salah satu alasan yang ditetapkan di atas.

Tetapi untuk perkawinan sirri, hanya dimungkinkan itsbat nikah dengan alasan dalam rangka penyelesaian perceraian. Sedangkan pengajuan itsbat nikah dengan alasan lain (bukan dalam rangka perceraian) hanya dimungkinkan jika sebelumnya sudah memiliki akta kawin dari pejabat berwenang. 18

Jangan lupa, bila telah memiliki akta nikah, harus segera mengurus akta kelahiran anak-anaknya ke Kantor Urusan Agama (KUA) atau Kantor Catatan Sipil setempat agar status anak tersebut sah di mata hukum. Jika pengurusan akta kelahiran anak ini telah lewat 14 (empat belas) hari dari yang telah ditentukan, terlebih dahulu harus mengajukan permohonan pencatatan kelahiran anak kepada pengadilan negeri setempat. Dengan demikian, status anak-anak dalam akta kelahirannya bukan lagi anak di luar kawin. ${ }^{19}$

\section{b. Melakukan Perkawinan Ulang}

Perkawinan ulang dilakukan layaknya perkawinan menurut agama Islam. Namun, perkawinan harus disertai dengan pencatatan perkawinan oleh pejabat yang berwenang pencatat perkawinan (KUA). Pencatatan perkawinan ini penting agar ada kejelasan status bagi perkawinan seseorang. Namun, status anak-anak yang lahir dalam perkawinan bawah tangan akan tetap dianggap sebagai anak di luar kawin, karena perkawinan ulang tidak berlaku surut terhadap status anak yang dilahirkan sebelum perkawinan ulang dilangsungkan. Oleh karenanya, dalam akta kelahiran, anak yang lahir sebelum perkawinan ulang tetap sebagai anak luar kawin, sebaliknya anak yang lahir setelah perkawinan ulang statusnya sebagai anak sah yang lahir dalam perkawinan.

18 Kompilasi Hukum Islam (KHI) Kepres No. 1 Tahun 1991, h. 33.

${ }^{19} \mathrm{Ibid} ., \mathrm{h} .34$. 


\section{c. Bagi yang beragama non-Islam}

Perkawinan ulang dan pencatatan perkawinan. Perkawinan ulang dilakukan menurut ketentuan agama yang dianut. Penting untuk diingat, bahwa usai perkawinan ulang, perkawinan harus dicatatkan di muka pejabat yang berwenang. Dalam hal ini di Kantor Catatan Sipil. Jika Kantor Catalan Sipil menolak menerima pencatatan itu, dapat digugat di PTUN (Pengadilan Tata Usaha Negara).

\section{d. Melakukan pengakuan anak}

Jika dalam perkawinan telah lahir anak-anak, dapat diikuti dengan pengakuan anak. Yakni pengakuan yang dilakukan oleh ayah atas anak yang lahir di luar perkawinan yang sah menurut hukum. Pada dasarnya, pengakuan anak dapat dilakukan baik oleh ibu maupun ayah. Namun, berdasarkan pasal 43 Undang-Undang No. 1 Tahun 1974 tentang Perkawinan yang pada intinya menyatakan bahwa anak yang lahir di luar perkawinan yang sah tidak mempunyai hubungan perdata dengan ayahnya hanya kepada ibu dan keluarga ibunya. Untuk mendapatkan hubungan perdata yang baru, seorang ayah. dapat melakukan Pengakuan Anak. Namun bagaimanapun, pengakuan anak hanya dapat dilakukan dengan persetujuan ibu, sebagaimana diatur dalam pasal $284 \mathrm{KUH}$ Perdata (BW). ${ }^{20}$

Menurut penulis ada dua langkah untuk meminimalisir eskalasi nikah sirri sebelum terjadi nikah sirri itu sendiri, langkah tersebut pertama, perlu ditingkatkannya kualitas penyelenggaraan Suscatin (kursus calon pengantin) oleh Kantor Urusan Agama (KUA). Kedua, lebih diperlonggar lagi persyaratan poligami.

\section{Ditingkatkannya Kualitas Penyelenggaraan Suscatin (Kursus Calon Pengantin)}

Sebagai upaya menanggulangi eskalasi nikah sirri, maka langkah yang tepat adalah diintensifkannya dan dimaksimalkannya penyelenggaraan Suscatin oleh Kantor Urusan Agama (KUA).

20Subekti, Komentar terhadap Kitab Undang-undang Hukum Perdata, (Jakarta: Pradnya Paramita, 1980), h. 48. 
KUA seyogyanya mewajibkan calon pengantin ikut Penyelenggaraan Kursus Calon Pengantin (Suscatin) dan harus dijadikan sebagai salah satu persyaratan pendaftaran perkawinan. Sudah menjadi kodrat alam, bahwa dua orang manusia dengan jenis kelamin yang berlainan, seorang perempuan dan seorang laki-laki, ada daya saling menarik satu sama lain untuk hidup bersama. ${ }^{21}$ Untuk meligitimasi hidup bersama itu dibuat peraturan yang mengatur perihal perkawinan.

Untuk menghindari kekacauan dan menciptakan kerukunan rumah tangga, kedamaian serta kesejahteraan abadi dari perkawinan tersebut, maka pemerintah dalam hal ini Departemen Agama berinisiatif menggalakkan program peningkatan kualitas keluarga dikhususkan bagi calon pengantin. Program ini menjadi salah satu syarat bagi calon pengantin untuk mengikuti prosedur pendaftaran pernikahan, namun penyelenggaraannya belum berjalan sebagaimana yang diharapkan.

Menurut analisis peneliti bahwa pelaksanaan praktik kursus calon pengantin (suscatin) di KUA sangat tepat yaitu dengan diterapkannya pemberian dan penanaman materi yang menyangkut munakahat, maka jika mereka melaksanakannya dengan penuh kesadaran dan ketulusan maka dapat mengurangi fenomena eskalasi nikah sirri.

Menurut penulis, materi Suscatin yang paling utama adalah tentang dampak negatif nikah sirri dari berbagai segi: (1) segi hukum; (2) segi psikologi anak; dan (3) segi agama.

\section{Lebih Diperlonggar lagi Persyaratan Poligami}

Ketatnya persyaratan untuk poligami juga telah menjadi salah satu pemicu nikah sirri. Tidak sedikit suami yang ingin poligami, namun demikian karena istrinya tidak mengizinkan, maka menempuh jalan nikah sirri. Demikian pula akibat ketatnya poligami, suami mengambil jalan pintas yaitu selingkuh. Perselingkuhan tersebut ketika terbongkar menimbulkan reaksi besar dari istri dan istri memilih cerai.

Mengamati kenyataan tersebut, penulis berpendapat agar persyaratan poligami diperlonggar guna mengurangi fenomena nikah sirri. Ketatnya 1981), h. 7. 
persyaratan poligami memiliki dampak yang cukup luas, mulai dari kasus nikah sirri, perselingkuhan, pembunuhan terhadap istri, dan perzinahan.

Hukum perkawinan nasional menganut asas monogami. Hal ini diatur dalam Pasal 3 Ayat (1) Undang-Undang Nomor 1 Tahun 1974, bunyinya: "Pada azasnya dalam suatu perkawinan seorang pria hanya boleh mempunyai seorang istri. Seorang wanita hanya boleh mempunyai seorang suami. " Ketentuan pasal ini secara kental ditransfer dari garis hukum yang terdapat di dalam QS. al-Nisa' [4]: 3 yang meletakkan dasar monogami bagi suatu perkawinan.

Akan tetapi, undang-undang tersebut memberi kemungkinan kepada seorang suami untuk melakukan poligami. Bagi seorang suami yang ingin berpoligami diharuskan meminta izin kepada pengadilan. Permintaan izin tersebut adalah dalam bentuk pengajuan perkara yang bersifat kontentius/sengketa. ${ }^{22}$ Agar pengadilan dapat mengabulkan permohonan izin poligami tersebut, pengajuan perkara tersebut harus memenuhi alasanalasan sebagaimana diatur dalam Pasal 4 Undang-Undang Nomor 1 Tahun 1974, yakni: 1) Istri tidak dapat menjalankan kewajibannya sebagai istri; 2) Istri mendapat cacat badan atau penyakit yang tidak dapat disembuhkan; 3) Istri tidak dapat melahirkan keturunan.

Alasan-alasan tersebut di atas bersifat fakultatif dan bukan bersifat imperatif-kumulatif, artinya salah satu saja dari tiga hal itu dijadikan alasan permohonan poligami ke pengadilan dan pemohon dapat mendukung alasan permohonannya dengan bukti-bukti yang cukup, maka permohonannya untuk beristri lebih dari satu orang dapat dikabulkan oleh pengadilan.

Persyaratan lain yang harus dipenuhi oleh seorang suami yang akan mengajukan permohonan izin berpoligami kepada pengadilan, sebagaimana diatur dalam Pasal 5 adalah: 1) harus ada persetujuan dari istri; 2) harus ada kepastian bahwa suami mampu menjamin keperluankeperluan hidup istri-istri dan anak-anak mereka; 3)harus ada jaminan bahwa suami akan berlaku adil terhadap istri-istri dan anak-anak mereka.

22Perkara poligami bukan perkara voluntair yang hanya terdiri dari pihak pemohon saja, tetapi perkara poligami merupakan perkara kontentius, perkara yang ada lawan, yaitu istri terdahulu, dan istri tersebut ditempatkan sebagai termohon, hal ini karena hak-hak dan kepentingannya terganggu dan mungkin pula dirugikan. 
Persyaratan yang tercantum dalam Pasal 5 Undang-Undang Nomor 1 Tahun 1974 ini bersifat kumulatif, artinya Pengadilan Agama/Mahkamah Syar'iyah hanya dapat memberi izin poligami kepada seorang suami apabila semua persyaratan tersebut telah terpenuhi. Jika satu syarat saja tidak terpenuhi, maka Pengadilan Agama/Mahkamah Syar'iyah harus menolak permohonan tersebut.

Selanjutnya, dalam Buku II Pedoman Mahkamah Agung $\mathrm{RI}^{23}$ dijelaskan; bahwa pada saat pengajuan permohonan izin poligami dari seorang suami, harus pula diajukan permohonan penetapan harta bersama dengan istrinya terdahulu. Jika permohonan penetapan harta bersama itu tidak diajukan, ada dua hal yang dapat terjadi.

Pertama, istrinya yang terdahulu dapat mengajukan gugatan rekonvensi (gugat balik) tentang penetapan harta bersama. Kedua, jika istrinya terdahulu tidak mengajukan rekonvensi, Pengadilan Agama harus menyatakan permohonan poligami tersebut tidak dapat diterima. Dari ketentuanketentuan peraturan tersebut tampak jelas bahwa untuk melakukan poligami dibutuhkan persyaratan yang sangat berat, tidak hanya kesanggupan berlaku adil, tetapi diperlukan pula persetujuan dari istri terdahulu. Di sini tampak sekali bahwa Undang-Undang sangat mempersulit bagi seseorang untuk melakukan poligami.

\section{F. Kesimpulan}

Perkawinan sirri termasuk salah satu perbuatan hukum yang kurang dikehendaki oleh undang-undang; karena terdapat kecenderungan kuat dari segi sejarah hukum perkawinan, bahwa perkawinan di bawah tangan termasuk perkawinan ilegal. Meskipun demikian, dalam Pasal 5 ayat (1) KHI terdapat informasi implisit bahwa pencatatan perkawinan bukan sebagai syarat sah perkawinan; tetapi sebagai alat untuk menciptakan ketertiban perkawinan. Oleh karena itu, dalam Pasal 7 ayat (3) KHI diatur mengenai itsbat nikah bagi perkawinan sirri. Dengan kata lain, perkawinan sirri adalah sah; tetapi kurang sempurna. Ketidaksempurnaan itu dapat dilihat dari ketentuan Pasal 7 ayat (3) KHI tersebut.

\footnotetext{
${ }^{23}$ Mahkamah Agung RI, Buku II Edisi 2007, tentang Pedoman Teknis Administrasi dan Teknis Peradilan Agama, 2008, h. 133.
} 
Apabila seorang anak dilahirkan secara tidak sah dalam pengertian hukum positif (perkawinan secara sirri), maka ia bisa disebut sebagai anak luar kawin (anak alam), sebagai akibatnya: pertama, tidak ada hubungan nasab kepada laki-laki yang mencampuri ibunya dalam pernikahan sirri. Kedua, tidak ada saling mewaris melainkan hanya dapat mewaris dari pihak ibu dan kerabatnya.[]

\section{Daftar Pustaka}

Burhanuddin, Nikah Siri: Menjawab Semua Pertanyaan tentang Nikah Siri, Yogyakarta: Pustaka Yustisia, 2010.

Hazm, Ibnu, al-Muhalla, ditahqiq oleh Muhammad Saqir, Juz IX.

Juzai, Ibnu, al-Qawanin al-Fiqhiyyah, Beirut: Dar al-Kitab al-Ijtimiyyah, tth.

Kompilasi Hukum Islam (KHI), Kepres No. 1 Tahun 1991

Koro, Abdi, Perlindungan Anak di Bawah Umur dalam Perkawinan Usia Muda dan Perkawinan Siri, Bandung: Alumni, 2012.

Mahkamah Agung RI, Buku II Edisi 2007, tentang Pedoman Teknis Administrasi dan Teknis Peradilan Agama, 2008.

Muzakar, Abdul Aziz, Mengenang Sang Tokoh dari Timur. Fajar, 1998.

Prodjodikoro, Wirjono, Hukum Perkawinan di Indonesia, Bandung: Sumur Bandung, 1981.

Rusyd, Ibnu, Bidâyah al Mujtahid Wa Nihâyah al Muqtasid, Juz. II, Beirut: Dâr Al-Jiil 1409 H/1989.

Shaltut, Mahmud, al-Fatawa, Kuwait: Dar al-Qalam, tth.

Soekarno, Di bawah Bendera Revolusi, 1957.

Subekti, Komentar terhadap Kitab Undang-undang Hukum Perdata, Jakarta: Pradnya Paramita, 1980.

Sudomo, Otobiografi Sang Prajurit, Mabes TNI-AL, 2010

al-Zuhaili, Wahbah, al-Fiqh al-Islämi wa Adillatuh, Juz VII, Damaskus: Dar alFikr, 1989, hlm. 71.

http://berita. okemetro. com/id/read/2013/04/05/33/787139, diakses tanggal 13 Oktober 2015. 
http://jambiupdate. com/artikel-polygami-subur-mimpi-pajak-multy-rogresif. html, diakses tanggal 13 Oktober 2015.

http://www. mui. or. id/index. php?start=9, diakses tanggal 13 Oktober 2015

http://umarabduh. blog. com/2012/03/10/1342/, diakses tanggal 13 Oktober 2015. 
